\title{
ARTICI.FS
}

Dol

10.11606/issn.2525-3123 gis.2021.181512

INTERCULTURALITIES IN DANCE: RECREATING ARGENTINA'S IDENTITY IMAGINARY

\section{SILVIA CITRO'}

Universidad de Buenos Aires - CONICET, Buenos Aires, Argentina, 1406 - contacto@antropologiadelcuerpo.com

\section{ABSTRACT}

This article analyzes how Argentine cultural policies between 2010 and 2015 sought to challenge the traditional identity imaginary of Argentinians as White Europeans. For this purpose, I initially made a genealogy of the main transformations of these policies and imaginaries to later focus on the performances of the Combinado Argentino de Danza (CAD) in the celebrations to commemorate the birth of Argentina as a nation state organized by the National Cultural Ministry. CAD was the first group on the local scene to propose combining national folk genres that reevaluate indigenous influences with hip hop, modern dance and electronic music, prompting artists from

KEYWORDS

Performance;

Identity

Imaginaries; Cultural Policies; Interculturality; Argentina. different regional and esthetic origins to work together. This case forms the basis for my examination of the ways in which global multiculturalist ideologies have been reworked locally as political attempts to legitimize a new intercultural, popular and non-sexist national imaginary.

1 This research has been funded by CONICET and the 2020-2023 UBACYT program (20020190100238BA): "Corporality, materiality and sound: Approaches from popular religiosities, sex-generic activisms and performance-research". 


\section{INTRODUCTION}

This paper examines the ways in which the cultural policies implemented in Argentina, mainly in the period 2010-2015, sought to challenge Argentinians' traditional identity imaginary as being of "White-European origin". Continuing with the line taken in previous research, I am interested in analyzing how national identity imaginaries are constructed, not only through textual inscriptions, verbal discourses, spaces and iconographies, but also through gestures, dances and music highlighting corporalities and sounds in public spaces, mobilizing intense collective emotions. For this reason, I propose to focus on one of the dance groups the Argentine state chose to place center stage in that period: Combinado Argentino de Danza (CAD). Formed in 2011, this group was soon invited by the Ministry of Culture to participate in various important official events, including the celebrations in 2014 and 2015 to commemorate the birth of the nation. My interest in the CAD is based on the fact that it was the first group on the local scene to propose a novel esthetic modality that combined local folk genres that re-evaluated indigenous influences, hip hop, contemporary dance and electronic music.

During the period between the celebration of the Argentine Bicentennial in 2010, commemorating 200 years of independence, and 2015, the national government, under the presidency of Cristina Fernández de Kirchner, invited different artists to participate in a series of mass events. The celebrations were held in the city of Buenos Aires, on stages set up in Plaza de Mayo (opposite Government House) and broadcast throughout the country by Argentine public television. As Connerton (1989) pointed out, commemoration rituals recalling the origins of various social groups are privileged moments in which to build "imagined communities", enabling collective identities and memories to be transmitted and recreated through shared ceremonies. In Latin America, celebrations commemorating independence from the colonial regime have been key rituals for the symbolic construction and political legitimation of national imaginaries. Throughout their history, they have appealed to performances in public spaces, which through different esthetics condense and express these identity imaginaries. These festivities became privileged spaces in which to analyze how states use and mobilize "culture as a resource" - to echo the well-known expression of Yudice (2002) - to actively intervene in public space and consolidate or, as in this case, transform national and regional identity imaginaries.

My initial hypothesis was that performances of this kind and by other invited artistic groups - such as the electronic and indigenous music ensemble Tonolec and the indigenous choir Chelalapi (Citro and Cerletti 2013), or the performance group Fuerza Bruta (Citro 2017) - reflected the intentions of a state cultural policy that sought to legitimize a national 
multicultural imaginary, in accordance with the global policies that were being implemented from the 1990s on. However, an analysis of these expressions and groups reveals the presence of particularities that differ from the globalized versions of neoliberal multiculturalism, such as the recurrence of a critical and popular interculturality, which highlights not only esthetic manifestations but also in Argentina the historically excluded social subjects themselves, especially mestizo, indigenous and Afro-descendant groups, in their current tensions and struggles.

Regarding the theoretical-methodological approach, this work draws on a series of classic socio-anthropological studies on performance (Turner 1992, Beeman 2003), dance (Browning 1995, Ness 1992, Reed 1998, Savigliano 1995, Katz and Greiner 2003) and music (Feld 1988, Turino 1999), among others, which emphasized how these expressions not only represent or symbolize existing identity positions, but can also actively intervene in their construction, as well as in the disputes and political strategies confronting the various groups and social actors over their legitimacy. Following this perspective in previous works (Citro 1997; 2009; 2012), I developed a methodological approach to analyze performances that I will partially discuss in this article, and which I will summarize below.

Basing myself on the perspective of intertextuality and dialogism developed by Bajtin (1999) and Voloshinov (1993), and the works of Bauman and Briggs (1999), I have stressed that both discursive and performative genres are constructed through their evolution in time and space in relation to other genres and social practices, past and present. Furthermore, in recent decades, these processes have tended to intensify, in the synergy between globalization, multiculturalism, growing access to the Internet, and the proliferation of postmodern esthetics and practices that look to hybridity. Consequently, it is possible to detect certain marks in performances reflecting these connections with other genres and historical-social practices that are fundamental to understanding the potential of each performance to construct meanings and intervene in political disputes. For this reason, I proposed a dialectical methodology that confronts: on the one hand, a "movement of approaching", in which the style and structuring of the performance are analytically described, and in which the network of sensations-emotions-feelings-meanings constructed by the performers in their practice search for comprehension; and on the other, a "movement of genealogical-contextual distancing", in which suspicion is exercised over that same performance as it seeks to reveal its possible connections with other current practices and meanings, as well as its possible past genealogies. Finally, to arrive at a synthesis that allows analysis of the effects or resonances of performances in the processes of construction, legitimation and dispute of identity imaginary and social roles, I have 
resorted to the articulation between Peircean semiotics with the proposed performativity theories by Butler (1999; 2002).

Different authors have highlighted how sonorities-corporeality-visualities construct meanings by appealing to iconic and indexical modalities, which precisely link them with other social practices and cultural meanings (Browning 1995, Lewis 1992, Turino 1999, and others). From the Peircean perspective, iconicity refers to that relationship in which some of the perceptible properties of the sign have within themselves isomorphisms or formal similarities with some of the properties of the referenced entity or object; while in indexicality there is an "existential bond" between the indexical sign and its object, which is based on their co-occurrence within one's own life experiences. That is why various indices "draw attention to their objects by blind impulse" and "redirect" the subjects to those objects by "contiguity" (Peirce cited in Verón 1993, 5). However, once these indexical relationships have been established, either by the reiteration of that link in time or by the affective impact that that sign once generated in a particular context, the real co-presence of the sign and the object is not required because, as Turino $(1999,235)$ points out, "the index can still bring" to the present those "experientially linked objects" from the past, and in turn, "new elements" of the present situation "can remain linked to the same sign". For this reason, these indexical forwardings contribute to the gestation of what Turino $(1997,235)$ calls a "semantic snowball", which I also consider to be "performative", since these forwardings accumulate, sediment and update (present) affectations and meanings. In other words, they "become present, are activated in the subjects and are relived as if the mediation between the vehicle sign and the indicated entities could be reduced or even canceled to merge into the same existential current", which materializes in bodies (Citro 2009, 227). For this reason, they are words, sounds, movements, objects, visualities, which have the potential to "do-carry out" what they say, sound, move and show.

From this perspective, the iconic and indexical meanings or these "performative effects" of performances emerge from the complex webs of genealogical and contextual connections. For this reason, to reveal how these effects are produced, it is essential to pay attention to the ways in which certain elements of style, mode of structuring, affectations and also, of event organization and its micro-politics, are de-contextualized and re-contextualized in other performances (Hanks 1989, Briggs and Bauman 1996), through direct quotes and/or reworkings, which, when recombined, contribute to make certain features visible and make others invisible, or exclude them. Thus, with this previous background, we can analyze how the experience of execution and perception of a certain performance produces different "effects" (affects and meanings), mainly through these two modalities, which are combined with each other. On 
the one hand, by fostering links of similarity (or iconicities) with everyday sociocultural experiences and meanings or other esthetic expressions that have been part of the biographies of the performers and viewers and that are quoted and reworked; and, on the other, by encouraging these references to also bring with them and update other experiences (sensations, affects and meanings), which were part of their previous perceptions/ performances (indexicalities).

For this reason, the ways in which performances construct meanings and performative effects do not depend solely on the communicative and political intentions of their makers, but also on the meanings that emerge from these iconic and indexical links that are gestated in complex genealogical-contextual plots and that often operate in a pre-conscious or unconscious way. Hence the margin of indeterminacy that persists in the different interpreters/performers.

Given the importance this theoretical-methodological approach brings to the genealogical-contextual approach to performances, in the first part of this article I will review the main ways in which that imaginary identity of White-European origin was built in Argentina, based on the multiculturalist ideologies that spread in the 1990s, as well as the first fissures in it. I will highlight how these imaginaries have featured in the hegemonic musical and dance repertoires of Argentine folk, which will be questioned, reworked and recombined in CAD performances, a more detailed analysis of which I shall make in the second part.

\section{A GENEALOGICAL APPROACH: FROM THE WHITENING OF THE "MELTING POT" TO GLOBALIZED MULTICULTURALISM}

Various authors coincide in pointing out that Argentina is one of the Latin American countries where the legitimation of a "White" nation imaginary identity, fundamentally inheriting Western European traditions is strongest (Ratier 1971, Bartolomé 1987, Segato 1999). With the process of consolidation of the nation-state in the middle of the 19th century, the ruling elites began to intensify the military persecution of indigenous peoples as well as their forced assimilation to "Western and Christian civilization", as recognized in the Constitution of 1854, by promoting their conversion to Catholicism (Article 67, subsection 15). In the case of Afro-descendants, the most classic historiography spoke of a drastic decline in their numbers and even their disappearance during the 19th century as a result of their large-scale participation and mortality in the wars of independence, and in the later Paraguayan war (1864-1870), as well as in the 1871 yellow fever epidemic in Buenos Aires. However, recent research maintains that these theses on their early disappearance were attempts 
by the elites of that time to make the presence of people of African descent invisible and to build a "White European" society, pointing to the absence of studies on complex processes of miscegenation of this population (Reid Andrews 1989). Parallel to these processes, the ruling elites promoted European immigration, with Argentina being the second country after the United States to receive the largest number of immigrants at that time, numbering approximately 6.6 million. Although the dominant narratives of the "melting pot" projected a fusion of different ethnic and racial origins - which would diminish the differences between them and bring about a new and homogeneous "national being" - the European components were prioritized while the indigenous and Afro-descendants were rendered invisible.

During the governments of Juan Domingo Perón (1945-1955), cracks appeared in this imaginary. On the one hand, various policies were promoted to "protect" the aboriginal (Martínez Sarasola 1992), affording greater visibility to the problems of this population. On the other hand, there was a proliferation of policies designed to secure the "vindication and social inclusion" of popular sectors, especially of mestizo and rural workers, who started to migrate mainly from the north of the country to Buenos Aires to work in the industrial sector that was just beginning to develop at that time. These young people were in fact referred to as "little black heads" by the urban elites of European descent, which reflected the persistence of racist categories (Ratier 1971). As Gravano $(1985,87)$ points out, the contingents of "little black heads" led to a drastic increase in the population of Buenos Aires and its suburbs, which came to exceed $50 \%$ of the country's total. This social sector thus became one of the main beneficiaries of Peronism's social inclusion policies and the main architect of its electoral triumphs. Let's see how these imaginary identities intervened in the shaping of folk music and dance repertoire in Argentina.

In the 1940s, musicologist Carlos Vega $(1944 ; 1952)$ undertook one of the most important systematic documentations of "Argentina's folk music and dance". ${ }^{2}$ However, his studies did not include indigenous or Afro-descendant groups and considered that only a few folk genres contained indigenous roots from the Andean zone (the carnavalito and the baguala), but none were Afro. This repertoire creation differentiated Argentina from other Latin American countries, such as Bolivia, Peru, Colombia and Ecuador, in which Creole, indigenous and Afro-descendant musical and dance genres stand out, although with different visibility and legitimacy throughout their history. Thus, over a long period of time, in Argentina a musical and dance folk tradition was created, which not only tended 
to make indigenous and Afro-descendant influences invisible, but it also stylistically reformulated mestizo components in an attempt to reappraise those features that were closest to the European imaginary. A key example of this process is the treatment of the gaucho. This term refers to Creoles or mestizos from different rural regions who had historically coexisted with the indigenous people of the area and, in several cases, had rebelled against the White urban elites who took over their territories and tried to recruit them for agricultural purposes. However, in traditional folklore, the gaucho tended to be stripped of these attributes that were linked to both miscegenation and rebellion, to become an estheticized figure with a romantic air. Blache (1983) has analyzed how the traditionalist landowning sectors, aligned with the conservative and nationalist right, promoted this process: they tried to install this estheticized gaucho as a symbol of Argentine nationality to differentiate themselves from those European migrants, who had arrived in the country and whose upward mobility was seen as threatening. In short, in these processes of folklorization and reinvention of traditions, we can appreciate what Kirshenblatt-Gimblett $(1998,72)$ refers to as an "erasure of the ideological power of performance and its ability to confront the dominant social and political orders" since "at the heart of the traditionalization process lies the desire to mask power and domination questions."

It is important to add that during the Peronist government, folk music was promoted as one of the policies to build and legitimize a "national" and "popular" culture (Gravano 1985), and in an analysis by Hirose (2010), that period was key to legitimizing the repertoire of Argentine folk music and dances. Benza, Mennelli and Podhajcer $(2012,176)$ emphasize the confluence of three processes between 1940 and 1950: a) "support for studies on folk music and dances from a "scientific" perspective, as is the case of the works of Vega, as mentioned above; b) "the creation of teacher training" courses institutionalizing folk dances and the "inclusion of folklore on the school curriculum"; and c) the "creation of various ballet companies that represented and promoted them". Thus, in 1953, one of the most important folk-dance companies in Argentina was formed, led by dancers Santiago Ayala (El Chúcaro) and Norma Viola. This artistic couple created more than 160 choreographic works, many of which were adapted for the stage, while incorporating new choreographies designed to highlight skill and virtuosity, such as acrobatic figures in malambo, the only male solo dance genre that mainly features stomping. The style created by Ayala and Viola has been influential among later generations of dancers, and from 1990 until their respective deaths they directed the then recently created National Folk Ballet. One element to highlight is that when Norma Viola joined Santiago Ayala's ballet in 1954, she was a "classical ballet dancer" trained in one of the most prestigious ballet institutions in the country, namely the Instituto del Teatro Colón. The 
following images reflect fundamental the impact of European classical ballet in the National Folk Ballet company.

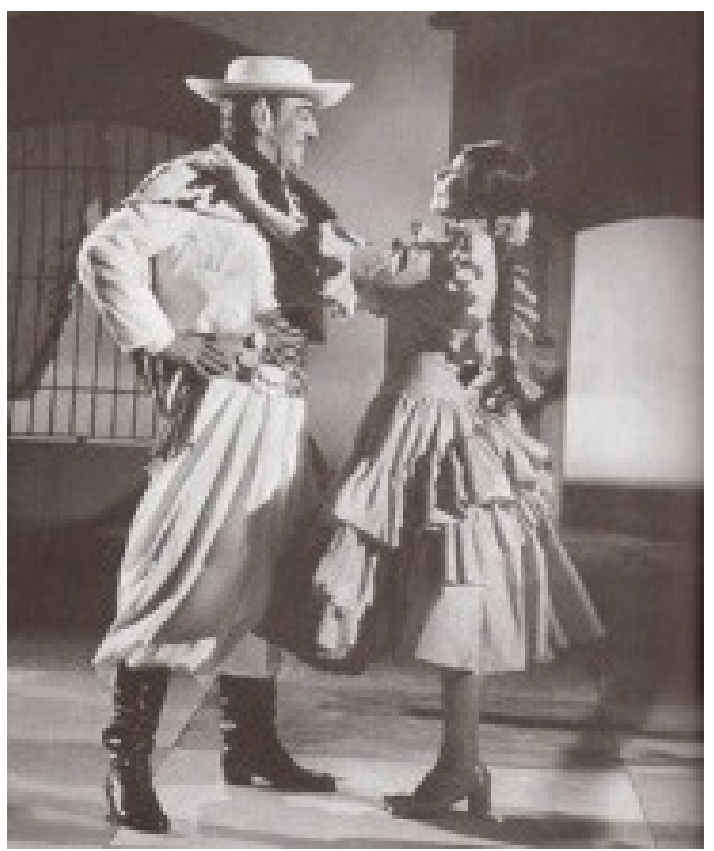

IMAGE 1: "Norma Viola and el Chúcaro in New York", no date or author. Source: http://tierrayarteasociacioncivil.blogspot.com.ar/2012/08/ santigo-ayala-el-chucaro.html

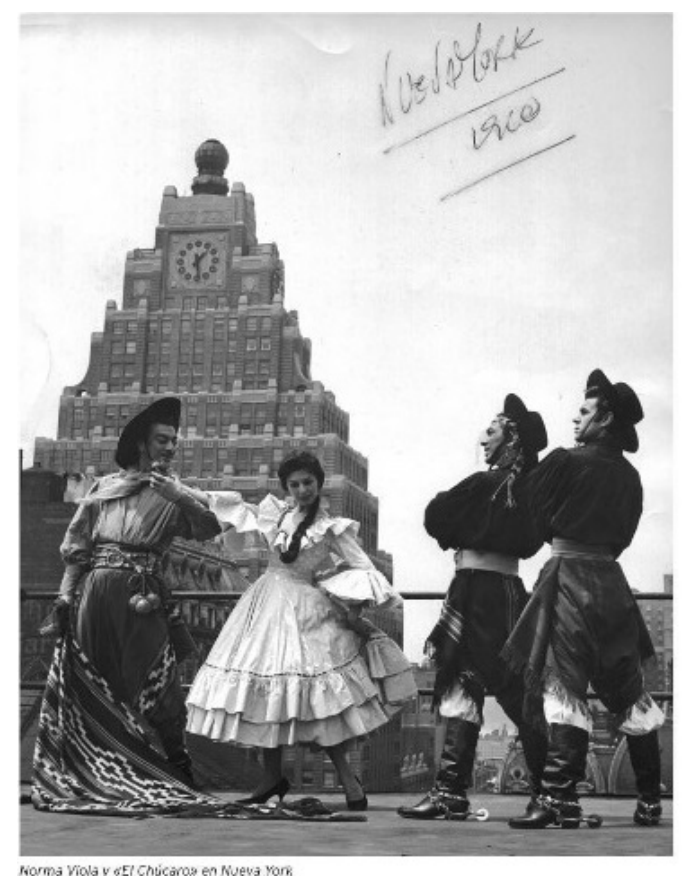

IMAGE 2: "El Chúcaro and Norma Viola in one of their many film appearances", no date or author. Source: http://www. laautenticadefensa.net/76228, accessed in June 2015. Originally published in Antes y después, Santiago Ayala "el Chúcaro" y Norma Viola, by J. C. Guillen, 2009, Editorial Balletin Dance. 

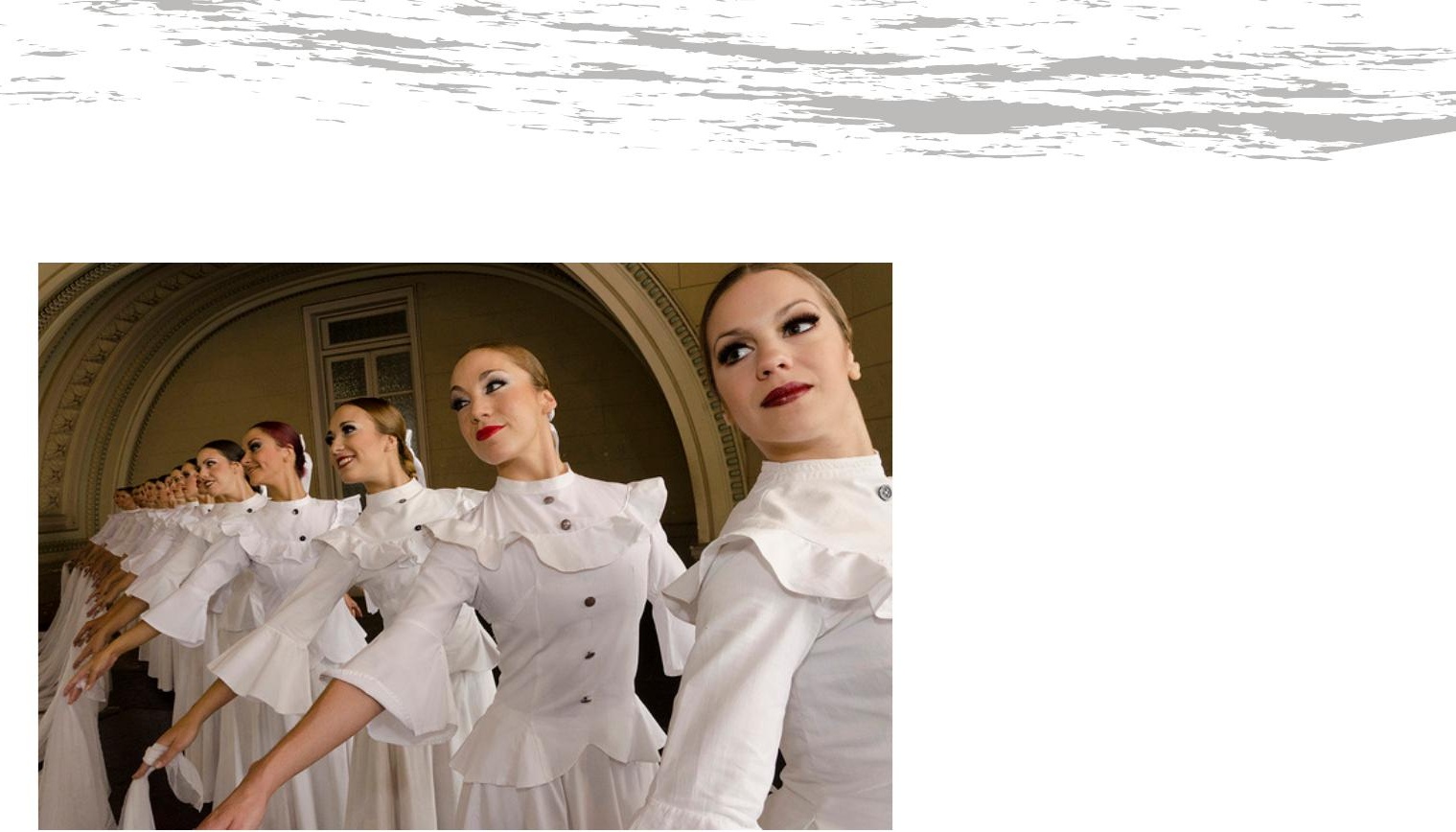

IMAGE 3: Official website of the National Folk Ballet, no author, $2015^{3}$.

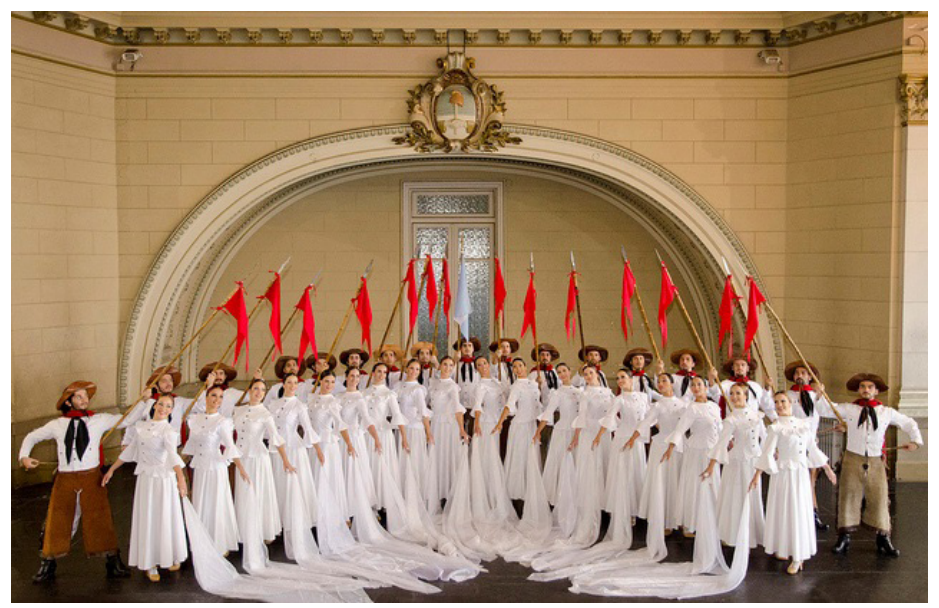

IMAGE 4: Official website of the National Folk Ballet, no author, 2015.

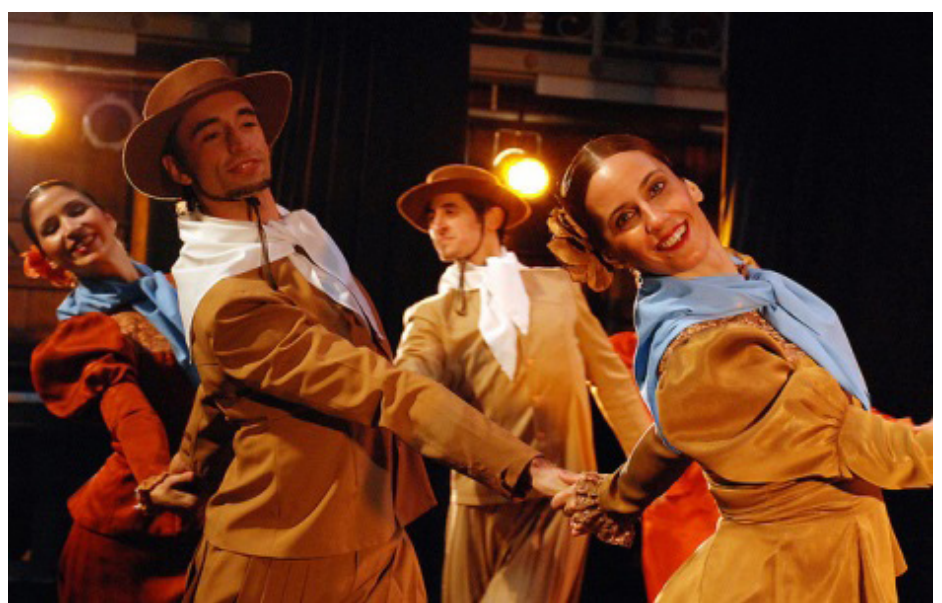

IMAGE 5: Official website of the National Folk Ballet, no author, 2015.

3 These and the following photographs are available at http://www.cultura.gob.ar/elencos/ ballet-folklorico-nacional/ (June 2015). 


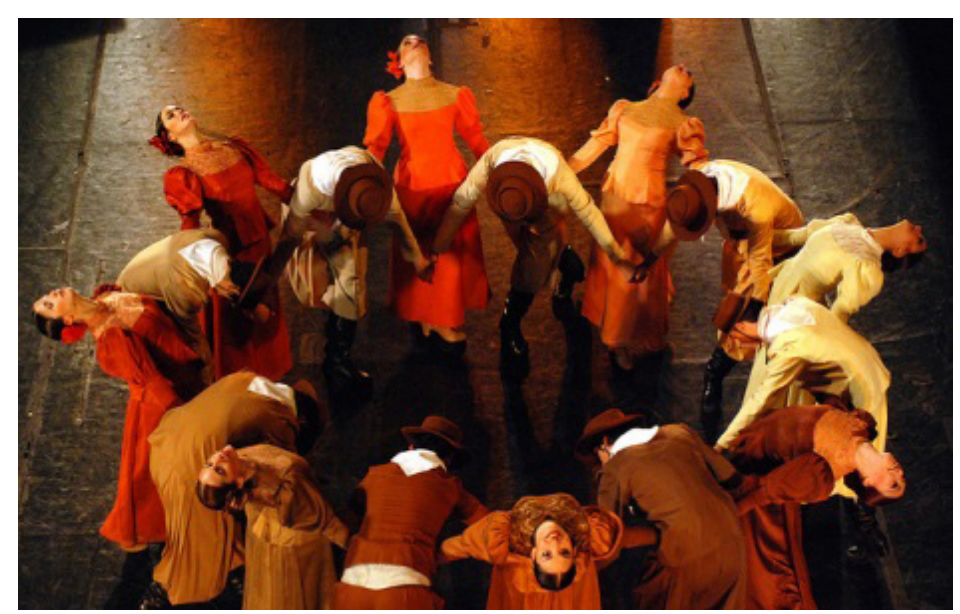

IMAGE 6: Official website of the National Folk Ballet, no author, 2015.

The slim silhouettes and the balanced proportions of the bodies, the hairstyles and make-up of the women as well as the upright postures and the body movements of the head, torso, arms and hands are clear references borrowed from European classical ballet. They tend to operate as a sign of expertise and professionalization in these and other official folk dance companies.

In image 6, we can also see the confluence between a spatial arrangement of the bodies that adopts the typical rounds of certain choreographies of indigenous Andean influences (such as the carnavalito) and the backward posture of the women, typical of classical ballet and also used in contemporary dance. Thus, it can be observed that even when these ballets incorporate into their works references that by analogy invoke a certain "indigenous" imaginary, they are subsumed to a technical-expressive language very largely based on classical ballet (Citro and Torres Agüero 2015). In short, folk dance professionalization is linked to a technical training based on certain principles of classical ballet, and is considered to be one of the most legitimate techniques for the physical training of the dancer. It then emerges in the forms and proportions of the dancers' bodies, in their postures and gestures.

Returning to the historical synthesis, it is important to remember that between 1955 and 1983, Argentina lived through a troubled period that included successive coups d'état, outlawings of Peronism, and military dictatorships. Neither indigenous nor Afro-related matters occupied a place in the public agenda. However, in the early 1970s, the first indigenous political organizations in Argentina began to take shape, although the military dictatorship of 1976 meant that many of these processes had to be aborted. It was also at the beginning of the 1970s that the first anthropological investigations were conducted, documenting the musical and dance expressions of indigenous groups from the northern Andean region, Chaco and southern Patagonia, thanks to the pioneering work of 
Irma Ruiz and Jorge Novati. This work has been continued by colleagues from my University and myself. Only with the reestablishment of democracy in 1983 and with the inauguration of Raúl Alfonsín of the Radical Party was National Law 23,302 of 1985 on Indigenous Policy and Support for Aboriginal Communities enacted. This law recognizes the ethnic and cultural preexistence and the rights of these peoples, and is still in force.

In the 1990s, with the return of Peronism to power under President Carlos Menem, a period of neoliberal policies and reduction in the size of the State began, ending in a deep economic and political crisis during 2000-2001. In this period, the first influences of the multiculturalist discourses promoted by international organizations can also be observed. They favored the emergence of previously invisible peoples, groups and cultural expressions, which began to claim rights in the name of their identity and to obtain legal recognition and even financial resources from transnational and national organizations. In this context, in 1994 a new National Constitution was approved, which for the first time included the recognition of a multicultural past and present, whose main references were indigenous peoples, although not Afro-descendants (Art. 75, Sec. 17). However, this legal recognition did not imply a better quality of life for these populations. As various authors have pointed out, coexistence and respect for all cultures equally, as propounded by multiculturalism, operated as the ideological other face concealing a political economy of inequality that became entrenched under neoliberalism (Zizek 1998, Segato 1999, Lacarrieu 2000, Grüner 2002). Walsh (2008) considers it to be a functional multiculturalism that "seeks to promote dialog and tolerance without affecting the causes of social and cultural asymmetry currently in force", and therefore, "assumes cultural diversity as the central axis (...) leaving aside the devices and patterns of institutional-structural power that maintain inequality".

One cultural policy that reflects this articulation of multiculturalist ideologies under neoliberalism was the process of tango patrimonialization. In 1999, tango was recognized as an "integral part of the cultural heritage of the city" of Buenos Aires, and in 2001 a proposal was made by the Argentine and Uruguayan States to include it on the Representative List of the Intangible Cultural Heritage of Humanity of UNESCO. The description of tango presented in the UNESCO list highlights precisely the multicultural character of this expression, which was born among:

[...] popular classes of the cities of Buenos Aires and Montevideo. In this region, where European migrants, descendants of African slaves and natives (Creoles) mix, an amalgam of customs, beliefs and rites was produced and transformed into a specific cultural identity. (...) the music, dance and poetry of tango are both an incarnation and a vector of diversity and cultural dialogue. (Source: https:// ich.unesco.org/es/RL/el-tango-00258). 
As can be seen, the European component is mentioned first of all, followed by the African component, while the indigenous peoples are absent, since they could hardly be included under the term "native" or "Creole", i.e., already mestizo, or mixed-race. It should be noted here that, given its origin in the cities, tango has tended to be considered as a genre apart from folk music or dance, consolidating the urban/rural division and, in this case, the division between the city of Buenos Aires and the other provinces in the country. In other words, Buenos Aires, the port city that received all the immigrants, is assigned urban tango, while the colloquially called "interior of the country" with mestizo predominance is assigned "rural folk" music and dance. In relation to the Afro component of tango, in recent decades some musicians and researchers such as Juan Carlos Cáceres and later Pablo Cirio (2006) have investigated and reappraised these influences, arguing over the origin of the word and the sources that testify that Afro-descendants practiced this genre in its beginning. However, earlier musicological studies such as those by Vega (1944) and then Novati (1980) disregarded these possible influences. Beyond this musicological controversy, it is interesting to note that this emphasis on identifying an Afro origin for tango helped to place it within a multicultural and non-racist identity imaginary, more in line with the global cultural policies of the time.

It is important to add that, as Morel (2010) points out, UNESCO was initially reluctant to approve this presentation because tango was not considered to be an expression under threat requiring "urgent safeguard measures". However, after several changes it was finally accepted in 2009 . This presentation revealed how heritage policies prioritized an expression of great cultural vitality and, above all, one that was widely successful in the entertainment market, especially on tourist circuits. This helped to generate an exoticizing imaginary concerning "passion" in tango (Savigliano 1995). In the first photograph on the UNESCO site dedicated to tango as heritage, shown below, we can see how the impact of this process of spectacularization. In front of a large audience a couple on stage is apparently in the final pose of their choreography. She is wearing a shiny dress while he is wearing a jacket. The presence of postures, gestures and body movements typical of classical ballet training is once again evident, especially in the raised arm of the dancer and in the semi-kneeling position of both, poses which are not common in popular modes and more traditional dance places. 


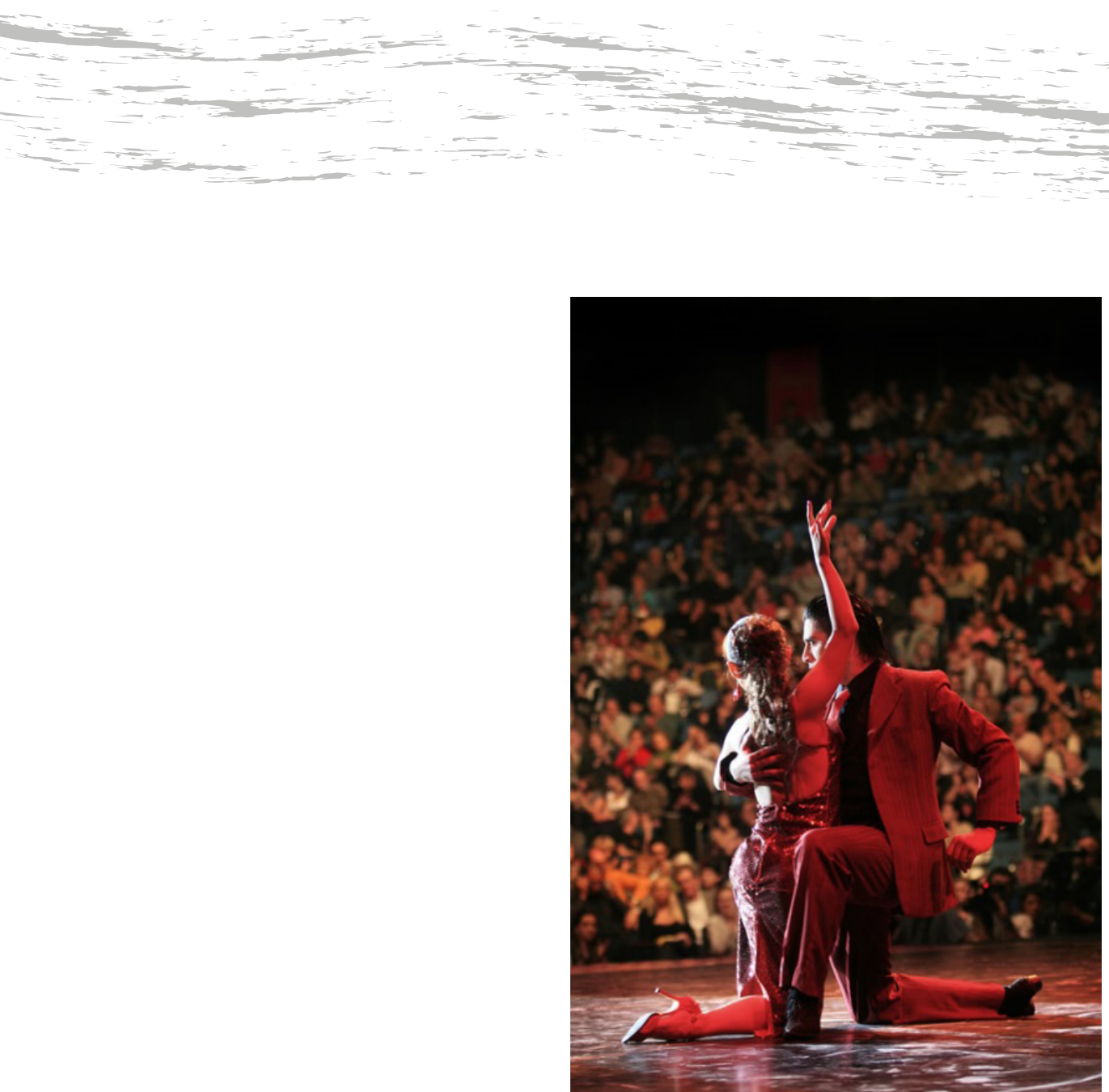

IMAGE 7: Official website of the Intangible Cultural Heritage of UNESCO. Author: Ministry of Culture of the City of Buenos Aires, 2008. Source: https://ich.unesco.org/es/RL/el-tango-00258 (access:

September 2016).

As stated by Prats $(1997,6)$, in these processes of "heritage activation [...] a selection is made and incorporated as heritage, either to endorse or to represent and sell a certain version of identity". Thus, in the case of tango, an expression that has operated as cultural capital and that generates important economic benefits was activated as "heritage". In addition, this reinforces the historical centralism of Buenos Aires in defining national imaginary, because despite being a specific expression of Río de la Plata and Buenos Aires culture, it has functioned metonymically as a symbol of a greater Argentine identity in the cultural market. Although other expressions existed in Argentina, under UNESCO criteria they were gradually "being forgotten" and deserved urgent "safeguard" measures - like many of the musical and dance expressions of indigenous groups. However, it would have been difficult for the national state of that time to have tried to activate them as heritage. On the one hand, they were ineffective for the imaginary of a national identity that has historically been built on a denial of the existence of the indigenous people of the "interior of the country" and by prioritizing the European origins of "Porteños"; and on the other, because those indigenous expressions are less profitable, as they tend to be esthetically less attractive for the esthetic sensibilities of the current cultural market (Citro and Torres Agüero 2015). What better, then, than the successful and passionate tango 
of Buenos Aires, which inherited the embrace of the migrant waltzes but redefined it with Afro traits to endorse that new imaginary of multicultural identity and, at the same time, to increase the economic benefits derived from its associated cultural industries.

Regarding more specifically the national cultural policies implemented by the governments of Néstor Kirchner and Cristina Fernández de Kirchner (2003-2015), some authors have analyzed the tendency to promote a multicultural imaginary that gave greater visibility to the native, Afro-descendant and mestizo peoples and even Latin American immigrants (Bayardo 2008, Citro and Torres Aguero 2015, Adamovsky 2016). In this respect, we should remember that during that period ties were consolidated with other Latin American leaders with whom certain economic, political and cultural guidelines were shared. Such was the case of Hugo Chávez in Venezuela, Lula da Silva in Brazil, Evo Morales in Bolivia, Rafael Correa in Ecuador and José Mujica in Uruguay, a situation that some authors have called the "swing to the left in Latin America" or, also more controversially, the "populist swing" (Damin and Petersen 2016). Thus, this new imaginary and its policies allowed many Argentines to symbolically bond with other Latin American nations with whom they now shared not only that "political shift", but also the recognition of those shared indigenous, African American and European cultural roots.

Beginning in 2010, the year of the Bicentennial, this imaginary was especially strengthened. In a previous paper (Citro 2017), I analyzed what I termed a "multicultural, but at the same time popular imaginary" in the Bicentennial celebrations, especially in the central parade by the performance group Fuerza Bruta. That parade represented a redefinition of national history that gave greater visibility and prominence to its indigenous, Afro and mestizo components, as well as to the popular political struggles of the previous century, for example, by the labor movement or the Mothers of Plaza de Mayo. In addition, I analyzed other symbolic acts of that year that reflected the reconfiguration of that imaginary identity. For example, what was formerly called Columbus Day on October 12, commemorating the "discovery" of America, was renamed "Day of Respect for Cultural Diversity". Several reforms were also carried out in the seat of the National Executive: a "Gallery of Latin American Patriots”, which included portraits of Túpac Amaru, Simón Bolívar, Augusto Sandino, Eva Perón, "Che" Guevara and Salvador Allende, was inaugurated; the room called "Cristóbal Colón" was renamed "Indigenous Peoples"; and the "Argentine Women" room featuring indigenous fighters was created. In addition, a decision was made to change the figure on the highest value banknote in the country: the image of Julio Argentino Roca, the general who led the military campaign against the 
native peoples of the south, was replaced by the bust of one of the main reference figures of Peronism and of the popular sectors, Eva Duarte de Perón. In 2014, the National Culture Secretariat was raised to the rank of Ministry, and for the first time was headed by a woman, who came from the world of folk music: singer-songwriter Teresa Parodi from Corrientes. Finally, in 2015, after several judicial and media disputes, the statue of Christopher Columbus standing behind government headquarters was removed and replaced by a statue of Juana Azurduy, a female "mestizo leader" who fought in the wars of independence. The statue was a gift from the president of Bolivia, Evo Morales" ${ }^{4}$.

I consider that these actions revealed the attempts to de-colonize key moments and spaces for the construction of a national identity imaginary, such as certain milestones on the official calendar, as well as the images and names that populate Government House and the banknotes in circulation. Thus, part of the imaginary the ruling elites have built around a "White" nation since the end of the 19th century, fundamentally inherited from Porteño European traditions, has been challenged and reformulated. We could also add it was built around a nation whose main heroes, dignitaries and other prominent personalities seemed to be only male (Citro 2017). However, despite the promotion of this new identity imaginary, conflicts with numerous indigenous communities persisted during this time, especially those linked to their territorial claims in the northeast and south of the country.

Next, I will analyze CAD's esthetic proposals as independent productions which, according to Walsh (2008), involved an "intercultural experience built from below", in this case articulated with these cultural policies that were built "from above", from the national state.

\section{THE ARGENTINE DANCE MIX: TOWARDS A POPULAR INTERCULTURALITY}

CAD is an independent dance company from the province of Buenos Aires, which began performing at the end of 2011 and was dissolved in early 2019. In Argentina, groups that perform outside the official casts, ballets and orchestras that operate in state theaters and cultural centers

\footnotetext{
4 The symbolic importance of these acts is also clear to see in the inauguration of Mauricio Macri's neoliberal government in 2015, when a large part of these reforms were abandoned. Both the gallery of the Latin American Patriots and the statue of Juana Azurduy were removed from Government House. In the celebrations of the May Revolution, the traditional parades by the armed forces once again acquired a fundamental role and figures of animals were put on the new bank bills. Also, in public speeches, the president said that Argentinians "come from ships" and that "in South America we are all descendants of Europeans" (Página 12 newspaper, 01/25/2018), generating fierce controversy.
} 
are called "independent". However, especially until 2015, the CAD and other independent groups were invited to participate in festivals and other state events and/or received different grants to support artistic creation. This situation changed dramatically with the new government that was installed in 2015.

One of the main characteristics of CAD is that they define themselves as a "mixture" of artists from different origins, as stated on their website: "Hip hop, contemporary dance and folk artists from different formations and life experiences carry out a constant process of training, dissemination and creation of dance actions"5. This mixture is also present in its name, which alludes to the "mix", although highlighting the Argentine component especially present in folk genres. Although their name identifies them as a dance company, comprising a total of 11 male dancers and female dancers, they also clarified that it was made up of "musicians, set designers, video artists, illuminator, DJ Villa Diamante and a manager and producer". Another feature that characterized them was their intention not only to dance in theaters, but above all in "the street, poor neighborhoods or unconventional places" such as nursing homes or hospitals. They thus considered "art as a tool for inclusion and social transformation" and their dance as "the dance that advances for a social cause". Finally, another feature of the group is that many of their performances were combined with a series of participatory workshops, which they called "A Possible Dance" and were held "in various voices and with an unlimited number of participating students, promoting the desire to dance and the search for what is one's own always in relation to the other".

These esthetic and political choices by CAD are linked to the peculiar origin of the group. Its director, Andrea Servera, is a renowned dancer who performed her first works in the 90s on the independent dance circuit of Buenos Aires with the group El Descueve, one of the main references of dance-theater of that time. In 2000, Andrea began working at Fundación Crear Vale la Pena, an NGO created in 1997 by dancer Inés Sanguinetti. This NGO was one of the first in Argentina to offer "social integration programs for young socially vulnerable people", through various artistic and community activities, at a time when the first consequences of the crisis caused by neoliberal economic policies were making themselves felt. The Centro Cultural Puertas Abiertas (Open Doors Cultural Center) Foundation is located in Beccar, near Villa La Cava, one of the largest shanty towns in the north of Buenos Aires province, which was created in the " 40 s by workers emigrating from the northern provinces of the

5 In http://combinadodedanza.com.ar/ (September 2016).

6 Source: https://www.facebook.com/combinadoargentinodedanza/ (October 2016). 
country to suburban Buenos Aires, that is, to the municipal districts that surround the capital city 7 . In that space, Andrea forged a relationship with Laura Zapata and other young hip hop and folk artists trained in the Foundation's workshops. With these young people who, in many cases, were the grandchildren of those internal migrants, CAD was born. It should be noted that Laura Zapata had already coordinated her own "creative laboratory", Big Mamma, where she fused urban dances with Argentine folk, particularly by taking up the folk expressions of Santiago de Estero (the northern province where her family is from), and where she even began to learn Quichua, the indigenous language that certain families and communities continue to speak. As Andrea Cervera summed up in an interview, in CAD "different worlds come together, which is good because each one contributes to the group from their standpoint".

I shall now analyze the main stylistic features of the "mix" that CAD featured in its works. In their choreographies, they combined folk music and traditional instrumentation, which was intervened with electronic music performed by live DJs. Although there are moments of fusion between the various genres, many of the references used tend to preserve the characteristics of each genre, without one genre imposing or subsuming the instrumentation, timbres and melo-rhythmic forms of the others.

Regarding body image, an element that differentiated CAD from the more traditional folk ballets (such as the National Folk Ballet) was the diversity of bodies in the group, many of which deviated from the slender model and balanced proportions of the classical ballet dancer. Such is the case of certain stout males in the cast. Another differential element was the clothing, typical of everyday wear among middle and working class young people: jeans, T-shirts and sneakers, and occasionally a football shirt. The dancers only incorporated the "poncho" and sometimes a hat as the main references from traditional gaucho clothing, but it is precisely these garments that are still used in rural areas, and the poncho can also be seen in some towns and cities, although to a lesser extent.

For this reason, at least for an Argentine spectator/researcher, these uses do not generate such a strong "traditionalist" effect as they do with other "gaucho" costumes of folk ballets, which have now mostly ceased to be used in everyday life.

7 At the end of the ' 90 s, as a member of a dance-theater group, I participated in presentations at Centro Cultural Puertas Abiertas, in which some classmates also gave workshops. This allowed me to learn about the work of the Foundation at that time. You can also see the later paper on these workshops, prepared by Iuso and Greco (2012).

8 http://revistarevol.com/actualidad/combinado-argentino-de-danza/ (October 2016). 


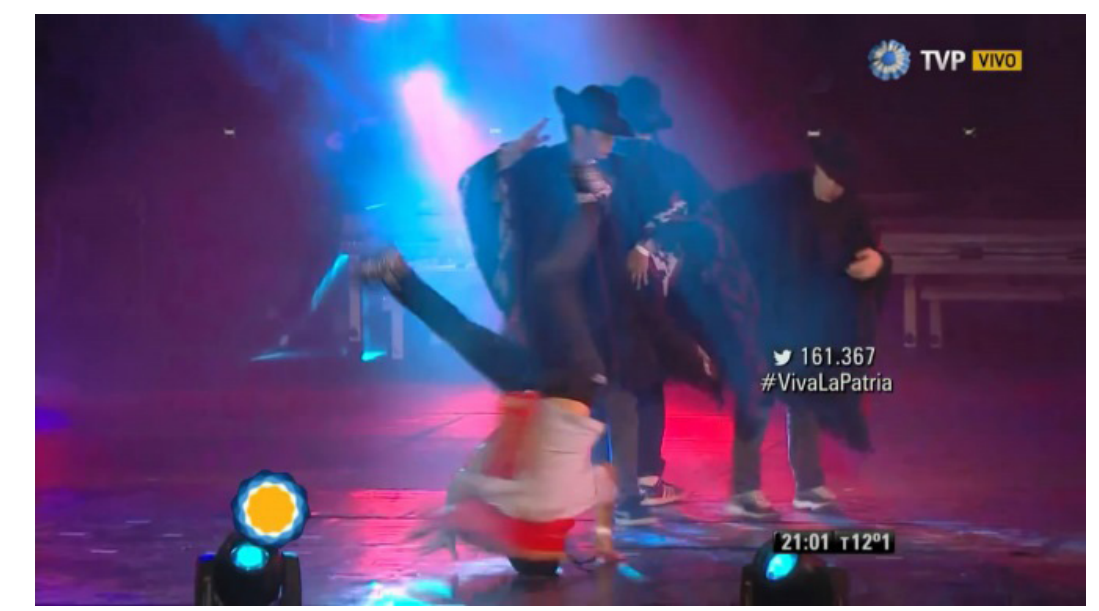

IMAGE 8: The CAD in the celebration of the May Revolution 205th Anniversary, 2015. Frame taken from Public TV footage. ${ }^{9}$

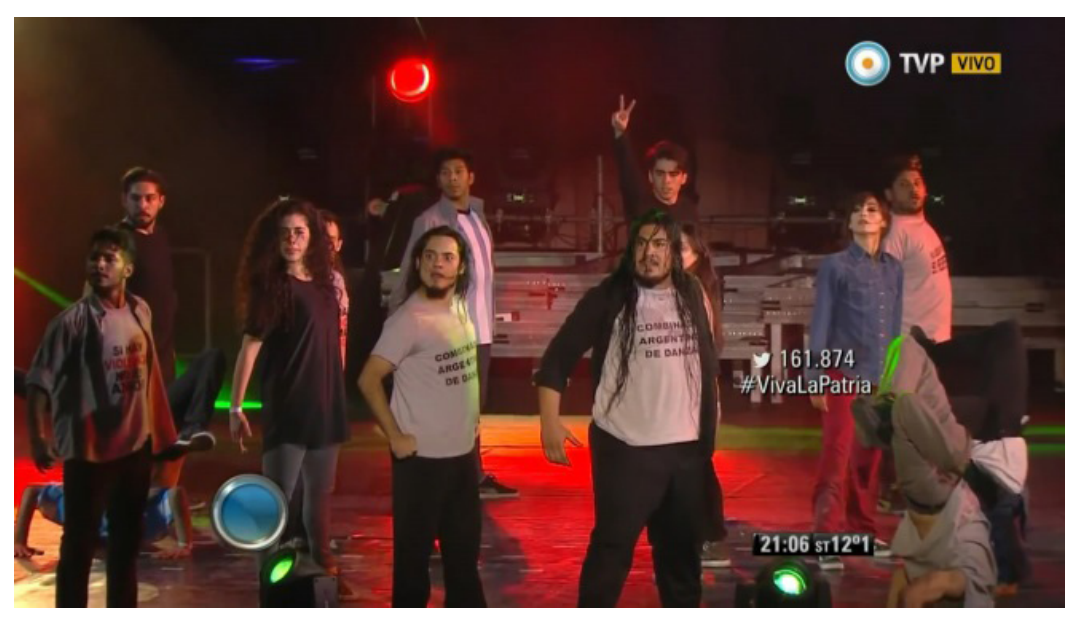

IMAGE 9: The CAD in the 205th Anniversary celebrations of the May Revolution, 2015. Frame taken from Public TV footage.

In relation to postures and body movements, both folk references (mainly from malambo) and hip hop were predominant. They follow the forms of these popular genres and are not transformed or stylized, according to the codes of classical ballet, as they are in traditional folk ballets. Thus, the intensity of the malambo stomping, with its downwards discharges, the breaks and destabilizations of hip hop, which break with the usual balances and postures of the body, tended to maintain their original design. Similarly, although to a much lesser degree, in some choreographies we were able to observe the fleeting appearance of certain leg movements typical of tango steps. The influence of contemporary dance was present in other movements that were also inserted, such as certain turns, jumps

9 This footage is available at https://www.youtube.com/watch?v=XMXT55usaZM (March 2017). 
and rolls, and above all in the diversity of ways in which the choreographic sequences were structured, that is, in the relationships between the dancers in their different spatial designs. In this regard, it is important to note that although brief moments both of solo sequences and of dances of couples occupied a central place, the movements of the whole group predominated. This type of group articulations differs from traditional folk dances (such as chacarera or zamba) in which couples or the male soloist (in the case of malambo) dance, and also in hip hop, in which soloists take turns to compete, in a central space, surrounded by other dancers.

As I mentioned above, malambo is the only "solo folk dance" in Argentina documented to date, and Vega (1952) described it as a "manly, demanding dance, a demonstration of vigor and skill", which involves different "changes" or footwork figures. It has often been interpreted as the "tournament for gauchos" among men vying for supremacy in variety, agility, speed, and accuracy of their dancing skills. Such masculine competition is also present in the origin of hip hop dance (break dance) during the 1970s among young African Americans and Latinos from the Bronx and Harlem in New York, and continues today under the forms of Breakdance Battles. However, this individual competition between dancers, typical of malambo and hip hop, is absent from the references of these genres made by CAD, whose choreographies involve a collective articulation of all bodies. They also incorporate various forms of direct contact, which are relatively uncommon in these genres, although they are in contemporary dance and in the influences it has received from contact-improvisation. Therefore, the structure of competing soloists was dismantled and replaced by ensemble scenes, in which the bodies share the same sequence of movement at certain times, while at others they overlap, converse and make contact in their diversity of movements. In spite of these important transformations, CAD choreographies continued to reproduce a certain tendency to highlight the virtuosity and bodily (and at times acrobatic) dexterity involved in many malambo and hip hop movements, which is aligned with the processes of spectacularization of many dance genres that seek to produce an effect of astonishment in the spectator (Barba and Savarese 1988, Beeman 2003). On the very large stages set up for the mass public presentations in Plaza de Mayo this trait of virtuosity seems to have been intensified for the benefit of the distant viewer.

Another transformation introduced by CAD was that women also participated in these traditionally male movements and, as we have seen, the clothing was the same for men and women. They took different roles and were not restricted to those differences that are naturalizing but which often limit bodily potentialities. The choreographic roles linked to heterosexual binarism (dexterity and vigor for men and delicateness for women) were deconstructed and incorporated into the movements of each one. 
In summary, those esthetic features that reinforce the heterosexual matrix and refer to competition (especially male) were excluded in the folk and hip-hop references proposed by CAD; and in contrast, movements of circulation, cooperation and reciprocity between the choreographic roles were promoted in an attempt to generate more horizontal links, although without losing the diversity of singularities. This intention is also apparent in the way in which the group offered its classes on the website of the independent cultural center where they took place:

We offer a space of physical reflection and dedication to movement; the body democratically put into action. Myself and the other, with our imaginations awakened in a state of action [...] building inter-relationships with an "other" and his/her singularity, training our listening capacity and perception, and challenging choreographic conventions, roles, hierarchies, to organically dance one's own way and the "other's way"10.

I believe that by highlighting gender equality, ensemble collaborative figures that "challenge hierarchies" and that diverse body, which dances its own way and in the way of others and is democratically put into action, CAD's choreographic and teaching activities were particularly akin to the orientation of the government, both with regard to gender policies as well as in its criticisms of the role of competition and individualism in neoliberal capitalism. Regarding gender policies of that time, it is worth noting that the Right to Gender Identity Law and the Equal Marriage Law were key milestones, especially among youth sectors, fostering critical reflection on heteronormative matrices, which influenced the field of dance. In this respect, it is also important to stress that these transformations in gender roles as well as in the dancers' clothing were already present in the independent folk circuit born at the time of the 2001 crisis, especially among youth sectors from the cities of Buenos Aires, Córdoba and Rosario. They later crossed over into tango with queer tango, danced by same-sex couples (e.g., Lucio and Montenegro 2012).

As Benza, Mennelli and Podhajcer $(2012,177)$ have pointed out "other stories" also began to acquire greater visibility and legitimacy in these independent folk spaces. They attributed indigenous and Afro origins to some folk genres and it was considered that "tradition has much more to do with the contemporary bodies and experiences of young people in the urban context than with the faithful copying or imitation of bodies from the past" (Benza, Mennelli and Podhajcer 2012, 177). This circuit evolved into workshops, clubs and spaces for experimentation and exchange with other artistic disciplines, and gradually became an alternative to the

10 In: http://ccmatienzo.com.ar/wp/entrenamiento-cad/ (September 2016). 
folk practiced in dance teacher training courses, ballets and traditionalist centers. Thus, genres such as chacarera and malambo were assigned Afro and also indigenous origins (Arico 2008). These genres are actually the most cited in CAD music and choreographies as their rhythmic configuration (mainly attributed to the Afro component) are particularly conducive to articulation with hip hop and electronic music. They converged in one of the esthetic pursuits of the group: "to build together [...] a particular and energetic universe, which is constantly transforming and in transformation ${ }^{11}$ ". It is worth noting that precisely these references to the energy displayed by the dancers or the intensity and strength of their performances and the emotion they arouse are the signifiers that most appeared in the comments I was able to collect from some of the spectators at the anniversary celebrations of the May Revolution in 2014 and 2015, at which the CAD performed.

Finally, in relation to these multiple CAD features, I would like to mention a brief final gesture observed in the 2015 performance and documented in image 9. One of the dancers (center back) raised his arm and made the "V" sign with his index and middle fingers with his palm facing outwards, a gesture that usually means $\mathrm{V}$ for victory or peace. However, in Argentina, and in the specific context of a popular festival in Plaza de Mayo organized by the government, it has become a sign adopted by the Peronist political movement that had ruled the country during the previous decade. Fleetingly and subtly towards the end, another feature appeared: this time that of an everyday, popular, politicized body, a body shared with the spectators-demonstrators present in the square, which has borne witness to many of the political struggles of Argentine history.

\section{FINAL THOUGHTS}

To conclude, I will return to the CAD's main esthetic and social features analyzed so far, in order to show how its proposals display a peculiar interculturality, which corresponded to the identity imaginary that national cultural policies sought to legitimize between 2010-2015.

A characteristic element of this group was that it proposed a montage of especially musical and choreographic esthetic elements of diverse historical-cultural and regional origins, appealing to the montage of direct references that operate as signs of those genres - and not so much to metaphorical reinventions that draw on iconic analogies or similarities. Thus, as we saw, malambo stomping or hip hop movements preserve the forms

11 In http://combinadodedanza.com.ar/ (September 2016). 
of movement typical of their original genres, while contemporary dance provides renewed ways of articulating the bodies of men and women in space, although it does not mean that they are substantially transformed in their postures, body images and movement styles.

A second feature was that neither of the summoned genres acquired supremacy over the others, nor did they subsume them. Instead, they imposed on them a technical-expressive language that substantially modifies the references of the other genres. Therefore, I consider that these modalities are close to that representation of postmodern multiculturalism, as a fragmentary mosaic of ethnic groups or cultures, which should not necessarily "merge" and "dilute" under the protection of a more legitimate (generally Western) model. As we have seen, the latter has happened in the stylizations of traditional folk dances and tango, subsumed under the technical-postural model of European classical ballet, corresponding to the previous melting pot miscegenation model that prioritized the White-European component.

A third feature was that, despite citing numerous elements of the various genres, others were excluded. Thus, those choreographic features of malambo and hip hop that challenged not only the esthetic but above all the political sensibilities of many of these young popular artists were excluded, such as heterosexist binarism and individualistic competition. Hence the esthetic-political sensibilities of the present excluded those features of an unwanted past.

Finally, a last feature was the heterogeneous composition of this group, which fostered not only inter-cultural but also inter-class and inter-gender ties in the course of its artistic endeavor, and in which, different stories of political-cultural struggle and resistance were also interwoven. In the CAD, young men and women met without hiding their different social and regional origins. Many of them were from historically excluded popular sectors, such as mestizo populations in the shanty towns of Greater Buenos Aires. They identified themselves as a group "advancing for a social cause", and included various excluded social groups in their presentations and workshops.

For all the above, I consider that the CAD experience differs both from the esthetic-ideological resources that operated in the 1940s folklorization processes and in 1990s multiculturalisms, which despite their differences coincided in the tendency to present identity imaginaries as free from tensions, internal differences or ambiguities, thus objectifying culture, as Guss $(2000,14)$ points out as "disemporalized things...": avoiding "any mention of real historical conditions and replacing it with staging creations from a mythical and timeless past". 
TRANSLATION

Analía Kerman and Lawrence Wheeler.
To close, I would add that the CAD proposal also differs from the neoliberal multiculturalism that, as Walsh $(2009,9)$ points out, is built "from above" to "continue promoting the benefits of capitalist accumulation" in the contemporary cultural market. They partially approach a "critical interculturality built from below [...] of and from people who have suffered a history of subjugation and subalternization [...] and who therefore seek to transform it". This is an inter-cultural, inter-class, inter-gender and social transformation experience that the CAD and other independent artistic groups "built from below", and which some state cultural policies "built from above" sought to make visible between 2010 and 2015 in Argentina to legitimize a new national, intercultural, popular and non-sexist imaginary. We could say that, as well as in esthetic terms, CAD performances re-versioned hip hop, Argentine folk and global electronic music, while, in political terms, the cultural policies of the government of that time also attempted to revert the global ideologies of neoliberal multiculturalism.

\section{BIBLIOGRAPHIC REFERENCES}

Adamovsky, Ezequiel. 2013. El color de la nación argentina. Conflictos y negociaciones por la definición de un ethnos nacional, de la crisis al Bicentenario. Jahrbuch für Geschichte Lateinamerikas, vol 49(1): 343-364.

Aricó, Héctor. 2008. Danzas tradicionales argentinas: una nueva propuesta. Buenos Aires: Vilko.

Bajtin, Mijail. 1985. Estética de la creación verbal. México: Siglo XXI.

Barba, Eugenio y Nicola Savarese. 1988. Anatomía del Actor. México: Gaceta/ International School of Theatre Anthropology.

Bartolomé, Miguel. 1987. Afirmación estatal y negación nacional. El caso de las minorías nacionales en América Latina. Suplemento Antropológico, vol. XXII N²: 15-30.

Bauman, Richard y Charles Briggs. 1996. Género, intertextualidad y poder social. Revista de Investigaciones Folklóricas, vol. 11: 78-108.

Bayardo, Rubens. 2008. Políticas Culturales: Derroteros y Perspectivas Contemporáneas. Revista de Investigaciones Políticas y Sociológicas, vol. 7(1): 17-29.

Beeman, William. 1993. The anthropology of theater and spectacle. Annual Review of Anthropology, vol. 22: 369-393.

Benza, Silvia, Yanina Menelli y Adil Podhajcer. 2012. Cuando las danzas construyen la Nación. Los repertorios de danzas folklóricas en argentina, Bolivia y Peru. En Cuerpos en Movimiento. Antropología de y desde las danzas, ed. Silvia Citro y Patricia Aschieri, 120-145. Buenos Aires: Biblos.

Blache, Martha. 1983. El concepto de folklore en Hispanoamérica. Latin American Research Review, vol. 18 (3): 135-148.

Browning, Bárbara. 1995. Samba. Resistance in motion. Bloomington and Indianápolis: Indiana University Press.

Butler, Judith. 1999. El género en disputa. El feminismo y la subversión de la identidad. Buenos Aires: Paidós.

Butler, Judith. 2002. Cuerpos que importan. Sobre los límites materiales y discursivos del "sexo". Buenos Aires: Paidós. 
Cirio, Norberto. 2006. La presencia del negro en grabaciones de tango y géneros afines. Temas de Patrimonio, vol. 16: 25-59.

Citro, Silvia. 1997. Cuerpos festivo-rituales: Un abordaje desde el rock. Tesis de Licenciatura en Ciencias Antropológicas, orientación sociocultural, Facultad de Filosofía y Letras, Universidad de Buenos Aires.

Citro, Silvia. 2009. Cuerpos Significantes. Travesías de una etnografía dialéctica. Buenos Aires: Editorial Biblos.

Citro, Silvia. 2012. Cuando escribimos y bailamos. Genealogías y propuestas teórico-metodológicas para una antropología de y desde las danzas. En Cuerpos en Movimiento. Antropología de y desde las danzas, ed. Silvia Citro y Patricia Aschieri, 17-64. Buenos Aires: Biblos.

Citro, Silvia. 2017. When "the descendants of the ships" began to mutate. Multicultural corporalities and sonorities in the Argentine bicentenary. AlBR - Revista Iberoamericana de Antropología, vol. 12 (1): 53-76.

Citro, Silvia y Adriana Cerletti. 2013. The female songs in Northeast Argentina. A comparative research between ancient female songs and their modern meaning. 42th World Conference of the International Council for Traditional Music. Shangai, China, 11-17 jul. 2013.

Citro, Silvia y Soledad Torres Agüero. 2015. Multiculturalidad e imaginarios identitarios en la música y la danza. Alteridades, vol. 50: 117-128.

Connerton, Paul. 1989. How Societies Remember. Cambridge: Cambridge University Press.

Damin, Nicolás y Petersen, Javier Mirko. 2016. Populismo entre Argentina y Europa. Sobre la transnacionalización de un concepto. Iberoamericana, vol. 16 (63): 16-32.

Feld, Steven. 1988. Aesthetics as iconicity, of style, or 'lift-up-over-sounding: getting into the Kaluli groove. Yearbook of Traditional Music, vol. 20: 74-113.

Gravano, Ariel. 1985. El silencio y la porfía. Buenos Aires: Corregidor.

Grüner, Eduardo. 2002. El fin de las pequeñas historias. De los estudios culturales al retorno (imposible) de lo trágico. Buenos Aires: Norma.

Guss, David. 2000. The Festive State: Race, Ethnicity, and Nationalism as Cultural Performance. Berkeley and Los Angeles: University of California Press.

Hanks, William F. 1989. Text and Textuality. Annual Review of Anthropology, vol. 18: 95-122.

Hirose, Mercedes. 2010. El movimiento institucionalizado: danzas folklóricas argentinas, la profesionalización de su enseñanza. Revista del Museo de la Facultad de Filosofía y Humanidades, Universidad Nacional de Córdoba, vol. 3: 171-186.

Katz, Helena y Christine Greiner. 2003. Corpomídia: a questão epistemológica do corpo na área da comunicação. Revista Húmus, vol. 1. Caxias do Sul: Secretaria Municipal de Cultura.

Kirshenblatt-Gimblett, Barbara. 1998. Destination Culture. Tourism, Museums, and Heritage. University of California Press.

Lacarrieu, Mónica. 2000. Construcción de imaginarios locales e identidades culturales en la Mundialización. Ponencia presentada en el Seminario de Nuevos retos y Estrategias de las Políticas Culturales frente a la globalización, 22 a 25 de noviembre de 2000. Barcelona: Institut d’estudis Catalans.

Lewis, Lowel. 1992. Ring of Liberation: Deceptive Discourse in Brazilian Capoeira. Chicago: Univ. Chicago Press.

Lucio, Mayra y Marcela Montenegro. 2012. Ideología en Movimiento. Nuevas modalidades del tango danza. En Cuerpos en Movimiento. Antropología de y desde las danzas, ed. Silvia Citro y Patricia Aschieri, 146-172. Buenos Aires: Biblos.

Martínez Sarasola, Carlos. 1992. Nuestros paisanos los indios. Buenos Aires: Emecé.

Morel, Hernán. 2011. 'Milonga que va borrando fronteras'. Las políticas del patrimonio: un análisis del tango y su declaración como patrimonio cultural inmaterial de la humanidad. Revista Intersecciones en Antropología, vol.12 (1): 163-176. 
Ness, Sally. 1992. Body, movement, and culture. Kinesthesic and visual symbolism in a Philipine community. Los Ángeles: Universty of California Press.

Novati, Jorge. 1980. Antología del Tango Ríoplatense. Desde sus comienzos hasta 1920. Buenos Aires: Instituto Nacional de Musicología "Carlos Vega".

Prats, Lorenc. 1997. Antropología y patrimonio. Barcelona: Ariel.

Ratier, Hugo. 1971. El cabecita negra. Buenos Aires: Centro Editor de América Latina.

Reed, Susan. 1998. The poetics and politics of dance. Annual Review Anthropology, vol. 27: 503-532.

Reid Andrews, George. 1989. Los Afroargentinos de Buenos Aires. Buenos Aires: Ediciones de La Flor.

Ruiz, Irma. 1998. Repensando la etnomusicología: homenaje al etnomusicólogo argentino Carlos Vega en el centenario de su nacimiento. Cuaderno de Música Iberoamericana, vol. 7: 15-25.

Savigliano, Martha. 1995. Tango and the political economy of passion. Westview Press: Boulder.

Segato, Rita. 1999. Identidades políticas/alteridades históricas: Una crítica a las certezas del pluralismo global. Anuario Antropológico, vol. 97: 161-196.

Turino, Thomas. 1999. Signs of Imagination, Identity, and experience: A Peircean Semiotic Theory for Music. Ethnomusicology, vol. 43(2): 221-255.

Turner, Victor. 1992. The Anthropology of Performance. New York: Paj.

Vega, Carlos. 1944. Panorama de la Música Popular Argentina en seis ensayos sobre la esencia del folklore. Buenos Aires: Editorial Losada.

Vega, Carlos. 1952. Las danzas populares argentinas. Buenos Aires: Instituto de Musicología "Carlos Vega".

Verón, Eliseo. 1993. La Semiosis Social. Buenos Aires: Gedisa.

Voloshinov, Valentin. 1993. El marxismo y la filosofía del lenguaje. Madrid: Alianza.

Walsh, Catherine. 2008. Interculturalidad crítica, pedagogía decolonial. En: Diversidad, interculturalidad y construcción de ciudad, ed. W. Villa y A. Grueso, 35-60. Bogotá: Universidad Pedagógica Nacional.

Yudice, George. 2002. El recurso de la cultura. Usos de la cultura en la era global. Gedisa: Barcelona.

Zizek, Slavoj. 1998. Multiculturalismo o la lógica cultural del capitalismo multinacional. En: Estudios Culturales. Reflexiones sobre el multiculturalismo, ed. Fredric Jameson y Slavoj Zizek, 137-188. Buenos Aires: Paidós

SILVIA CITRO holds a Ph.D. in Anthropology from the University of Buenos Aires (UBA 2003), where she also completed her Bachelor's and Teacher's Degree. She is currently an Associate Professor of the Arts at the Faculty of Philosophy and Letters of the UBA, and a Postgraduate Professor at the Faculty of Social Sciences of the UBA, FLACSO (Argentina) and the Faculty of Arts of the Francisco José de Caldas District University (Colombia). At the Institute of Anthropological Sciences of the UBA, she works as a CONICET researcher and, since 2004, she has coordinated the Anthropology of the Body and Performance research group (www.antropologiadelcuerpo.com). Email: csilvia7047@gmail.com

Use license. This article is licensed under the Creative Commons CC-BY License. With this license you can share, adapt, create for any purpose as long as you assign the work. 